\title{
33. NATURE OF THE LAYER 2/3 TRANSITION FROM A COMPARISON OF LABORATORY AND LOGGING VELOCITIES AND PETROLOGY AT THE BASE OF HOLE 504B ${ }^{1}$
}

\author{
Matthew H. Salisbury, ${ }^{2}$ Nikolas I. Christensen,${ }^{3}$ and Roy H. Wilkens ${ }^{4}$
}

\begin{abstract}
Compressional- and shear-wave velocities obtained by logging and laboratory measurements on samples from the base of Hole 504B between 1725 and $1836 \mathrm{~m}$ sub-basement are indistinguishable from classic Layer 3 velocities obtained by refraction $\left(V_{p}=6.7 \mathrm{~km} / \mathrm{s}, V_{s}=3.75 \mathrm{~km} / \mathrm{s}\right)$. Point counts of thin sections from this interval show that the rocks consist not of gabbro, but of greenschist facies metadiabase dikes dominated by plagioclase and actinolite. Comparison with thin sections and logs from higher levels suggests that the Layer $2 / 3$ boundary is a metamorphic front within the sheeted dikes controlled by the disappearance of chlorite, or a porosity transition marking the disappearance of interpillow voids and large-scale fractures, depending on whether the boundary is defined in terms of velocities or velocity gradients.
\end{abstract}

\section{INTRODUCTION}

Since Raitt (1963) first recognized that the oceanic crust can be divided into two distinct layers, Layers 2 and 3, which are separated worldwide by a major geophysical discontinuity, this boundary has been variously interpreted as a transition between basalt and gabbro (e.g., Fox and Stroup, 1981), dikes and gabbro or basalt and serpentinite, a tectonic boundary between such lithologies (Karson, 1990), a metamorphic front (Christensen, 1970; Christensen and Salisbury, 1975; Salisbury and Christensen, 1978), a crack or porosity front, or a pore pressure front. Because each of these interpretations can be logically defended but only one is likely correct at any one site, the only way to determine the nature of the Layer $2 / 3$ transition unequivocally is to determine the depth of the boundary geophysically, then drill through it and compare the actual petrology with logging and physical properties data across the transition.

To this end, the Deep Sea Drilling Project (DSDP) and its successor, the Ocean Drilling Program (ODP), have been drilling in Hole 504B for over 15 years, first occupying the site during Leg 69 and returning to deepen the hole and conduct geophysical studies on six subsequent legs: Legs 70, 83, 111, 137, 140 and the most recent, 148 (Shipboard Scientific Parties of Legs 68, 69 and 70, 1983; Shipboard Scientific Party, 1985, 1992a, 1992b, 1993). The hole is located in about $3 \mathrm{~km}$ of water in relatively normal crust on the south side of the Costa Rica Rift (Fig. 1). Magnetic anomaly patterns show the crust to be $6 \mathrm{~m} . y$. old and spreading at a half-rate of $7 \mathrm{~cm} / \mathrm{yr}$. Heat flow is high and conductive. Drilling to date has penetrated $2111 \mathrm{mbsf}$, of which $275 \mathrm{~m}$ is in sediments and the remaining $1836 \mathrm{~m}$ is in basement, making this by far the deepest hole ever drilled into oceanic basement. Although gabbro has not been recovered to date, the hole has penetrated a major petrologic boundary, the pillow basalt-sheeted dike transition, 600-800 m sub-basement (Shipboard Scientific Party, 1985) and has since been drilled an additional $1050 \mathrm{~m}$ into the sheeted dikes (Fig. 2).Significantly, the formation porosity decreased dramatically

'Alt, J.C., Kinoshita, H., Stokking, L.B., and Michael, P.J. (Eds.), 1996. Proc. ODP, Sci. Results, 148: College Station, TX (Ocean Drilling Program).

${ }^{2}$ Geological Survey of Canada Atlantic, Bedford Institute of Oceanography, Dartmouth, P.O. Box 1006, Nova Scotia B2Y 4A2, Canada. matts@agc.bio.ns.ca

${ }^{3}$ Department of Earth and Atmospheric Sciences, Purdue University, West Lafayette, IN 47907, U.S.A. chris@geo.purdue.edu

${ }^{4}$ Hawaii Institute of Geophysics and Planetology, School of Ocean and Earth Science and Technology, University of Hawaii, 2525 Correa Road, Honolulu, HI 96822, U.S.A. wilkens@ soest.hawaii.edu in this same transition zone (Becker et al., 1989) and the mineralogy has changed steadily with depth in response to increasing temperature and metamorphic grade (Alt et al., 1986; Shipboard Scientific Party, 1988, 1992a, 1992b, 1993). It is thus appropriate to ask, has Hole 504B already penetrated into Layer 3 ?

\section{VELOCITY STRUCTURE OF THE CRUST}

The above question can best be answered by reference to the geophysical data for the site summarized from many sources by Detrick et al. (1994) and presented in Figure 3. As can be seen in this figure, the compressional-wave velocity $\left(V_{p}\right)$ determined by sonobuoy studies (Collins et al., 1989), borehole seismic studies (Little and Stephen, 1985) and geophysical logging (Shipboard Scientific Party, 1993) increases rapidly with depth from 4.5 to $5 \mathrm{~km} / \mathrm{s}$ at the top of basement to about $6.5 \mathrm{~km} / \mathrm{s}$ at $1.2 \mathrm{~km}$ sub-basement and then increases more slowly to $6.7-6.8 \mathrm{~km} / \mathrm{s}$ at the base of the hole $(1.8 \mathrm{~km}$ subbasement). Because these techniques interrogate different volumes of crust along different ray paths at different frequencies, the overall similarity of the results suggests that the velocity structure of the crust in the vicinity of Hole 504B is laterally homogeneous, at least to the limits of resolution of refraction. If Raitt's definition of Layer $3\left(V_{p}=6.7 \pm 0.2 \mathrm{~km} / \mathrm{s}\right.$ at the top of the layer $)$ is superimposed on the data, it is clear that Hole 504B entered the first standard deviation $(6.5 \mathrm{~km} / \mathrm{s})$ at about $1.2 \mathrm{~km}$ sub-basement and reached mean Layer 3 velocities by the bottom of the hole at $1.8 \mathrm{~km}$. Detrick et al. (1994) interpret the Layer $2 / 3$ boundary in terms of a change in velocity gradient and place it at the inflection point at $1.2 \mathrm{~km}$. By either definition, then, Hole 504B has entered Layer 3, even though the hole ends in sheeted dikes and no gabbros have been recovered.

\section{LABORATORY VELOCITY MEASUREMENTS}

To determine the relationship between logging and seismic velocities and the velocities of the rocks themselves at the bottom of the hole, laboratory measurements of $V_{p}$ and $V_{s}$ were made on watersaturated samples collected during Leg 148 to hydrostatic confining pressures of $600 \mathrm{MPa}$ using the ultrasonic pulse transmission technique of Birch (1960). The measurements were made on 2.54-cmdiameter, 2- to 3-cm-long minicores, which were cut perpendicular to the core axis and jacketed with copper foil to prevent the pressure medium from invading the sample at elevated pressures. No measure- 


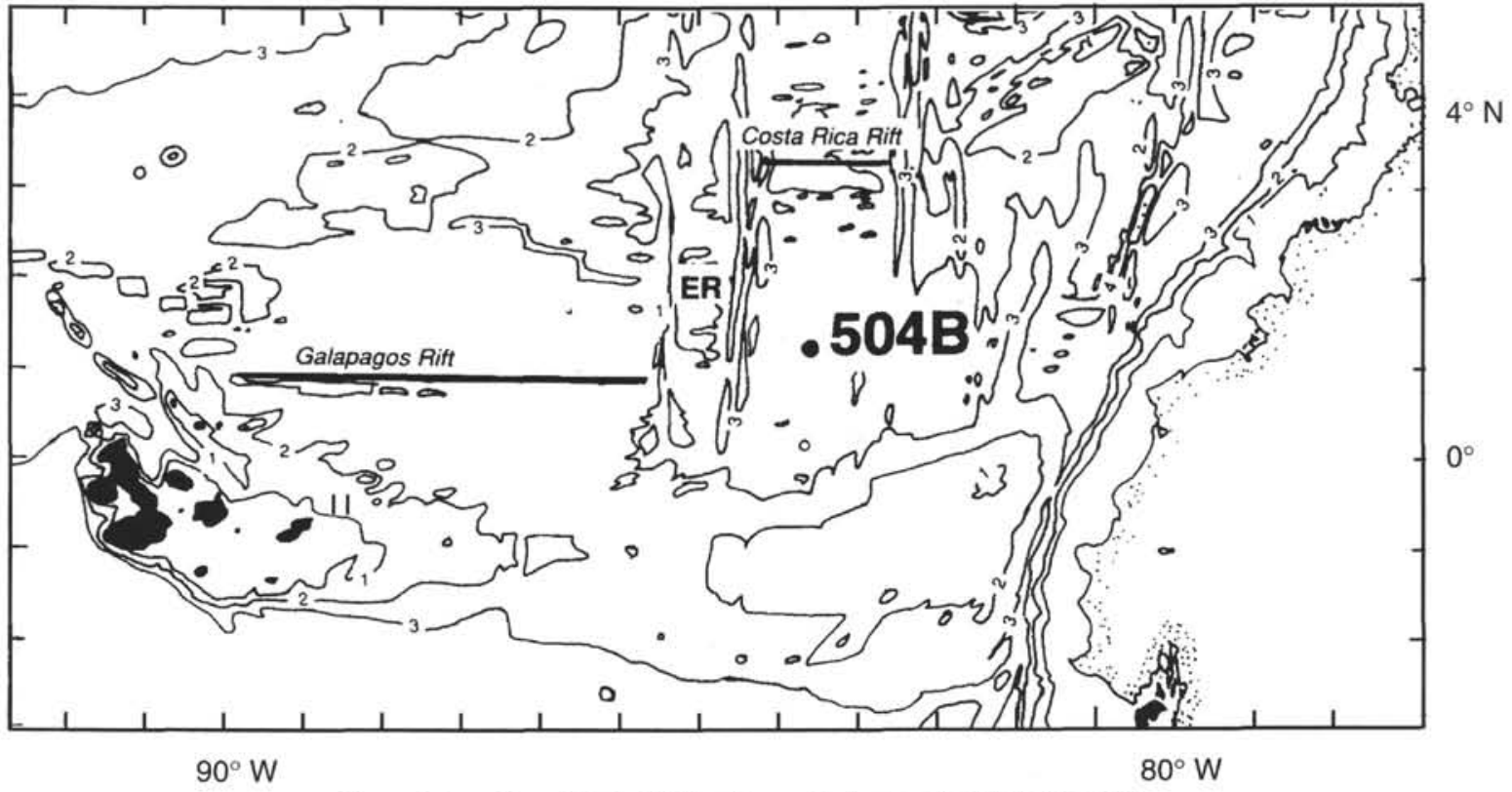

Figure 1. Location of Hole 504B on the south flank of the Costa Rica Rift.

ments were made for vertical propagation paths (parallel to the core) because the core material from Hole 504B shows no evidence of deformation or preferred crystallographic orientation and is thus expected to be isotropic at in situ pressures. Pore pressures were kept close to zero by placing a thin copper screen between the sample and the foil to provide space for water to drain during pressurization. Figure 4 shows $V_{p}$ vs. pressure for a typical sample from this data set; $V_{p}$ increases rapidly with increasing pressure to about $100 \mathrm{MPa}$ in response to the closure of microcracks and then increases much more slowly at higher pressures in response to the elastic properties of the constituent minerals of the rocks. The results, which are considered accurate to $0.5 \%$ for $V_{p}$ and $1 \%$ for $V_{s}$, are presented in Table 1 along with wet-bulk densities calculated from the masses and dimensions of the samples and porosities calculated from their wet- and dry-bulk densities.

\section{COMPARISON OF LABORATORY, LOGGING, AND SEISMIC VELOCITIES}

Compressional-wave velocities measured at room temperature and $100 \mathrm{MPa}$, the in situ pressure at the base of the hole, are shown in Figure 5 along with the Leg 148 velocity log and laboratory velocities from previous legs (Wilkens et al., 1983; Christensen and Salisbury,1985; Christensen et al., 1989; Iturrino et al., 1995). Also shown (solid line) is the best fit to the laboratory $V_{p}$ data at estimated in situ pressures after the velocities have been corrected to the in situ temperatures determined from geophysical logging (Shipboard Scientific Party, 1993) using a correction factor, $\delta V_{p}=-0.5 \times 10^{-3} \mathrm{~km} / \mathrm{s}^{\circ} \mathrm{C}$ (Christensen, 1979). Discussion of the $V_{\mathrm{s}}$ data will be postponed until shear wave logging and VSP data are available for comparison.

The corrected laboratory velocities presented in Figure 5 are significantly greater than logging velocities throughout the pillow basalts, the basalt/sheeted dike transition zone and the uppermost sheeted dikes to a lift-off point at about $925 \mathrm{~m}$ sub-basement. As the formation permeability is high in this interval $\left(10^{-13}-10^{-18} \mathrm{~m}^{2}\right)$ and formation porosities determined from resistivity logs are high compared to sample porosities (3\%-13\% vs. $3 \%-6 \%$; Salisbury et al., 1985; Becker et al., 1988; Anderson et al., 1992), it is clear that for- mation velocities are profoundly influenced by large-scale porosity (interpillow voids and open fractures) to at least the base of the transition zone.

In the sheeted dikes between 925 and $1725 \mathrm{~m}$ sub-basement, the corrected laboratory velocities are in good agreement with seismic velocities and maximum logging velocities. Because measured formation permeabilities and porosities $\left(<10^{-19} \mathrm{~m}^{2},<2 \%\right)$ approach laboratory (i.e., grain boundary) values for rocks in this interval, we conclude that the small discrepancy $(\sim 0.25 \mathrm{~km} / \mathrm{s})$ observed between laboratory and logging velocities throughout most of the sheeted dikes results from small joints and cooling cracks. The agreement between laboratory and refraction velocities in this interval suggests, but does not prove, that these cracks are localized around the borehole and are thus drilling-induced.

At the base of the hole, the velocities of the Leg 148 samples (solid circles) match those obtained by logging. Because formation porosities determined from resistivity logs are vanishingly small $(<0.1 \%$; Shipboard Scientific Party, 1993) in the interval drilled during Leg 148, it is clear that formation velocities at this level of the crust are controlled solely by petrology and state conditions (temperature and pressure). We thus conclude that velocities throughout the sheeted dikes from $925 \mathrm{~m}$ sub-basement to the base of the hole at $1836 \mathrm{~m}$ are controlled largely by petrology and confining pressure rather than by fracture porosity and that the velocity gradients observed in this interval, and by inference, throughout the upper levels of Layer 3, are controlled by changes in petrology and pressure.

\section{PETROLOGY OF THE SHEETED DIKES AND THE NATURE OF THE LAYER 2/3 BOUNDARY}

What, then, is the petrology at the top of Layer 3 and how does it vary with depth? On the basis of hand-sample and thin-section descriptions, the basement section from 780 to $1836 \mathrm{~m}$ sub-basement is composed of diabase dikes with varying amounts of chlorite (chl) and actinolite (act) replacing clinopyroxene (cpx) and plagioclase (plag) (Shipboard Scientific Party, 1985, 1988, 1992a, 1992b, 1993). Beginning during Leg 111 , point counts were routinely made on thin sections at closely spaced intervals down the hole (every 3-4 m, de- 


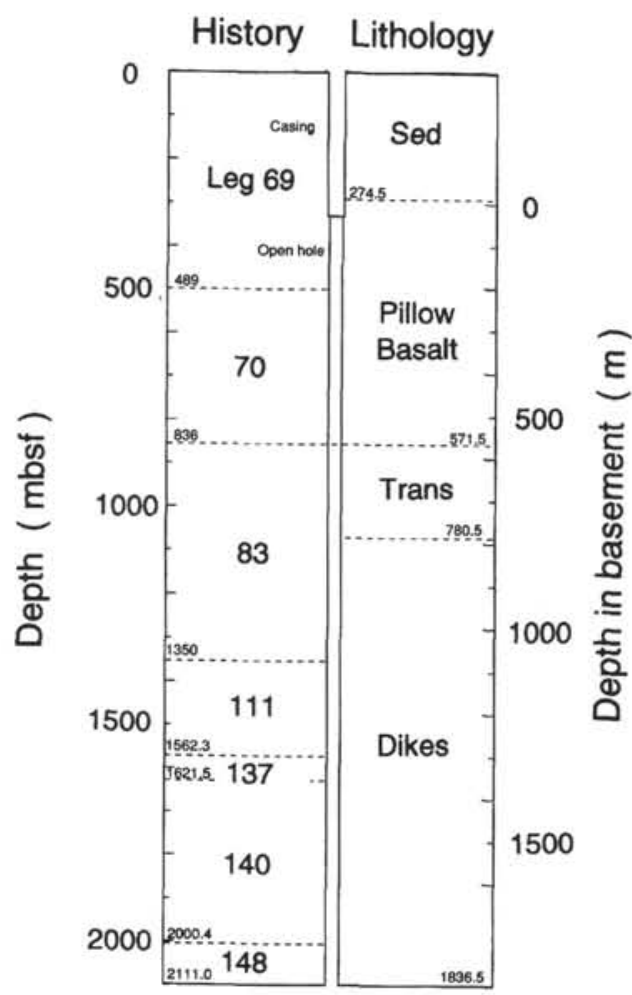

Figure 2. Drilling history and lithology vs. depth in Hole 504B.

pending on recovery, for a total of 220 thin sections). By plotting the average modal volume of the four most abundant minerals over 25 $\mathrm{m}$ intervals as in Figure 6, it is possible to estimate the actual abundances of the minerals that control velocity as a function of depth. From this figure, it is clear that chlorite is abundant, probably $>20 \%$ by volume, at the top of the dikes, but decreases to about zero by 1.8 $\mathrm{km}$ sub-basement, while actinolite increases at the expense of clinopyroxene from zero at the top to about $40 \%$ near the base of the hole. Because $V_{p}$ cpx $>V_{p}$ act $\gg V_{p}$ plag $\gg V_{p}$ chl, we conclude that the steady increase in $V_{p}$ observed in the logs in Hole 504B below 900 $\mathrm{m}$ sub-basement is controlled by increasing pressure and a decrease in chlorite with increasing metamorphic grade and that classic Layer 3 velocities are encountered when chlorite disappears altogether. Thus, if the Layer 2/3 boundary in Hole 504B is defined as the inflection point in the velocity-depth curve at about $1.2 \mathrm{~km}$, it appears to result from a porosity transition below which porosities are very low, whereas if the boundary is defined in terms of classic Layer 3 velocities, it appears to result from a metamorphic front. In either case, in Hole 504B, the boundary occurs in the sheeted dikes and has nothing to do with the presence of gabbro.

\section{ACKNOWLEDGMENTS}

MHS and RHW were able to participate on Leg 148 because of financial support provided by the Geological Survey of Canada and JOI-USSAC, respectively. The laboratory velocity measurements were conducted with support from the Office of Naval Research to N.I.C. Geological Survey of Canada Contribution No. 26795.

\section{REFERENCES}

Alt, J.C., Honnorez, J., Laverne, C., and Emmermann, R., 1986. Hydrothermal alteration of a $1 \mathrm{~km}$ section through the upper oceanic crust, Deep
Sea Drilling Project Hole 504B: mineralogy, chemistry, and evolution of seawater-basalt interactions. J. Geophys, Res., 91:10309-10335.

Anderson, R.N., Honnorez, J., Becker, K., Adamson, A.C., Alt, J.C., Emmermann, R., Kempton, P.D., Kinoshita, H., Laverne, C., Mottl, M.J., and Newmark, R.L., 1982. DSDP Hole 504B, the first reference section over $1 \mathrm{~km}$ through Layer 2 of the oceanic crust. Nature, 300:589-594.

Becker, K., Sakai, H., Adamson, A.C., Alexandrovich, J., Alt, J.C., et al., 1989. Drilling deep into young oceanic crust, Hole 504B, Costa Rica Rift. Rev. Geophys., 27:79-102.

Birch, F., 1960. The velocity of compressional waves in rocks to 10 kilobars. J. Geophys. Res., 65:1083-1102.

Christensen, N.I., 1970. Composition and evolution of the oceanic crust. Mar. Geol., 8:139-154.

, 1979. Compressional wave velocities in rocks at high temperatures and pressures, critical thermal gradients, and crustal low-velocity zones. J. Geophys. Res., 84:6849-6857.

Christensen, N.I., and Salisbury, M.H., 1975. Structure and constitution of the lower oceanic crust. Rev. Geophys. Space Phys., 13:57-86.

1985. Seismic velocities, densities and porosities of Layer 2B and Layer 2C basalts from Hole 504B. In Anderson, R.N., Honnorez, J., Becker, K., et al., Init. Repts. DSDP, 83: Washington (U.S. Govt. Printing Office), 367-370.

Christensen, N.I., Wepfer, W.W., and Baud, R.D., 1989. Seismic properties of sheeted dikes from Hole 504B, ODP Leg 111. In Becker, K., Sakai, H., et al., Proc. ODP, Sci. Results, 111: College Station, TX (Ocean Drilling Program), 171-176.

Collins, J.A., Purdy, M.G., and Brocher, T.M., 1989. Seismic velocity structure at Deep Sea Drilling Project Site 504B, Panama Basin: evidence for thin oceanic crust. J. Geophys. Res., 94:9283-9302.

Detrick, R., Collins, J., Stephen, R., and Swift, S., 1994. In situ evidence for the nature of the seismic layer $2 / 3$ boundary in oceanic crust. Nature, 370:288-290.

Fox, P.J., and Stroup, J., 1981. The plutonic foundation of the oceanic crust. In Emiliani, C. (Ed.), The Sea (Vol. 7): The Oceanic Lithosphere: New York (Wiley), 119-218

Iturrino, G.J., Christensen, N.I., Becker, K., Boldreel, L.O., Harvey, P.K.H., and Pezard, P., 1995. Physical properties and elastic constants of upper crustal rocks from core-log measurements in Hole 504B. In Erzinger, J., Becker, K., Dick, H.J.B., and Stokking, L.B. (Eds.), Proc. ODP, Sci. Results, 137/140: College Station, TX (Ocean Drilling Program), 273292.

Karson, J.A., 1990. Seafloor spreading on the Mid-Atlantic Ridge: implications for the structure of ophiolites and oceanic lithosphere produced in slow-spreading environments. In Malpas, J., Moores, E.M., Panayiotou, A., and Xenophontos, C. (Eds.), Ophiolites: Oceanic Crustal Analogues: Proc. Symp. "Troodos 1987": Nicosia, Cyprus (Minist. Agric. Nat. Resour.), 547-555.

Little, S.A., and Stephen, R.A., 1985. Costa Rica Rift borehole seismic experiment, Deep Sea Drilling Project Hole 504B, Leg 92. In Anderson, R.N., Honnorez, J., Becker, K., et al., Init. Repts. DSDP, 83: Washington (U.S. Govt. Printing Office), 517-528.

Raitt, R.W., 1963. The crustal rocks. In Hill, M.N. (Ed.), The Sea-Ideas and Observations on Progress in the Study of the Seas (Vol. 3): The Earth Beneath the Sea: New York (Wiley-Interscience), 85-102.

Salisbury, M.H., and Christensen, N.I., 1978. The seismic velocity structure of a traverse through the Bay of Islands ophiolite complex, Newfoundland, an exposure of oceanic crust and upper mantle. J. Geophys. Res., 83:805-817.

Salisbury, M.H., Christensen, N.I., Becker, K., and Moos, D., 1985. The velocity structure of Layer 2 at Deep Sea Drilling Project Site 504 from logging and laboratory experiments. In Anderson, R.N., Honnorez, J., Becker, K., et al., Init. Repts. DSDP, 83: Washington (U.S. Govt. Printing Office), 529-539.

Shipboard Scientific Parties of Leg 68 (Site 501), Leg 69, and Leg 70, 1983. Sites 501 and 504: sediments and ocean crust in an area of high heat flow on the southern flank of the Costa Rica Rift. In Cann, J.R., Langseth, M.G., Honnorez, J., Von Herzen, R.P., White, S.M., et al., Init. Repts. DSDP, 69: Washington (U.S. Govt. Printing Office), 31-173.

Shipboard Scientific Party, 1985. Hole 504B, Leg 83. In Anderson, R.N., Honnorez, J., Becker, K., et al., Init. Repts. DSDP, 83: Washington (U.S. Govt. Printing Office), 13-118.

1988. Site 504: Costa Rica Rift. In Becker, K., Sakai, H., et al., Proc. ODP, Init. Repts., 111: College Station, TX (Ocean Drilling Program), 35-251. 
1992a. Site 504. In Becker, K., Foss, G., et al., Proc. ODP, Init. Repts., 137: College Station, TX (Ocean Drilling Program), 15-55.

1992b. Site 504. In Dick, H.J.B., Erzinger, J., Stokking, L.B., et al., Proc. ODP. Init. Repts., 140: College Station, TX (Ocean Drilling Program), 37-200.

1993. Site 504. In Alt, J.C., Kinoshita, H., Stokking, L.B., et al., Proc. ODP, Init. Repts., 148: College Station, TX (Ocean Drilling Program), 27-121.

Wilkens, R.H., Christensen, N.I., and Slater, L., 1983. High-pressure seismic studies of Leg 69 and 70 basalts. In Cann, J.R., Langseth, M.G., Hon- norez, J., Von Herzen, R.P., White, S.M., et al., Init. Repts. DSDP, 69: Washington (U.S. Govt. Printing Office), 683-686.

Date of initial receipt: 19 August 1994

Date of acceptance: 24 February 1995

Ms 148SR-146

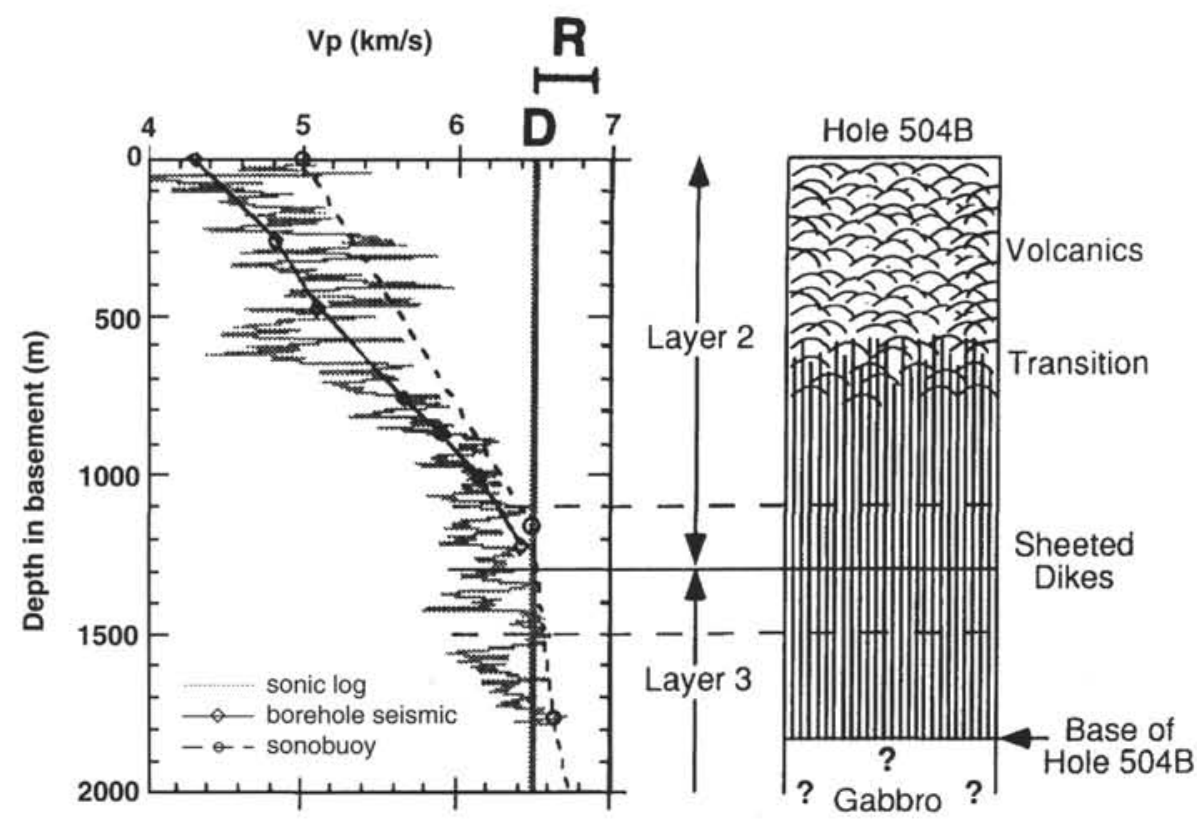

Figure 3. Compressional wave velocity $\left(V_{p}\right)$ structure vs. depth and lithology in Hole 504B (after Detrick et al., 1994). Column labeled D shows location of Layer $2 / 3$ boundary defined in terms of velocity gradients, whereas column labeled $\mathrm{R}$ shows Layer 3 compressional wave velocity range ( 1 standard deviation) as defined by Raitt (1963). By either criterion, Hole 504B has entered Layer 3.

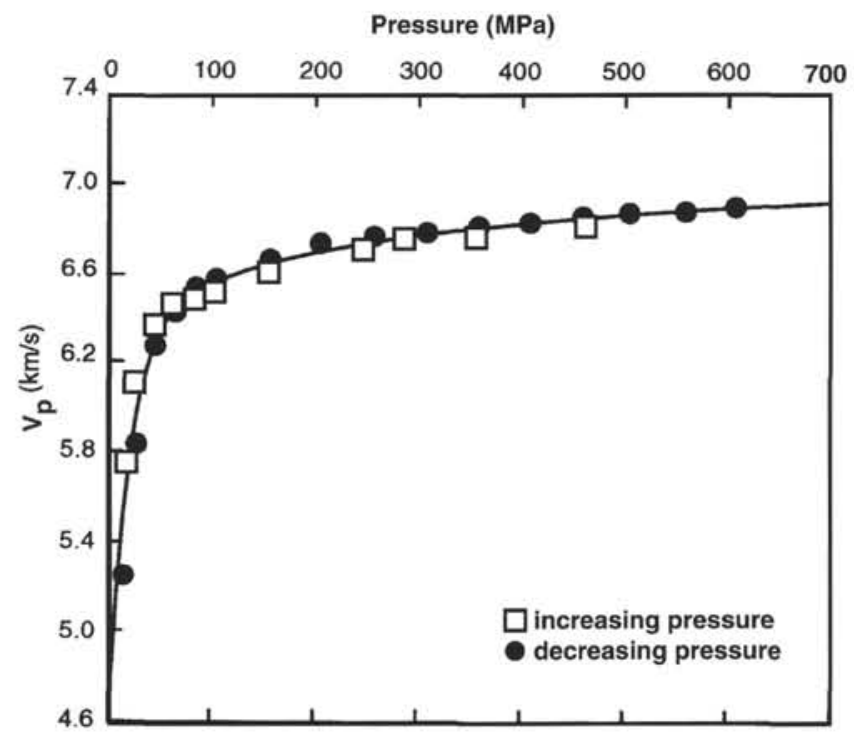

Figure 4. Compressional wave velocity $\left(V_{p}\right)$ vs. confining pressure for Sample 148-504B-239R-1, 41-45 cm. 
Table 1. Compressional- and shear-wave velocities vs. pressure for samples from Hole 504B.

\begin{tabular}{|c|c|c|c|c|c|c|c|c|c|c|c|c|}
\hline \multirow{2}{*}{$\begin{array}{l}\text { Core, section, } \\
\text { interval }(\mathrm{cm})\end{array}$} & \multirow[b]{2}{*}{$\rho$} & \multirow[b]{2}{*}{$\phi$} & \multicolumn{10}{|c|}{ Pressure (MPa) } \\
\hline & & & 0.2 & 0.4 & 0.6 & 0.8 & 1.0 & 2.0 & 3.0 & 4.0 & 5.0 & 6.0 \\
\hline 239R-1, 41-45 & 2.971 & 0.63 & & & & & & & & & & \\
\hline $\mathrm{P}$ & & & 5.859 & 6.269 & 6.438 & 6.522 & 6.572 & 6.703 & 6.777 & 6.830 & 6.872 & 6.906 \\
\hline $\mathrm{S}$ & & & 3.063 & 3.297 & 3.437 & 3.525 & 3.583 & 3.699 & 3.740 & 3.768 & 3.789 & 3.806 \\
\hline $240 \mathrm{R}-1,52-55$ & 2.934 & 0.61 & & & & & & & & & & \\
\hline $\mathrm{P}$ & & & 5.835 & 6.311 & 6.521 & 6.622 & 6.679 & 6.794 & 6.852 & 6.894 & 6.927 & 6.954 \\
\hline $\mathrm{S}$ & & & 3.202 & 3.393 & 3.499 & 3.563 & 3.603 & 3.686 & 3.722 & 3.746 & 3.765 & 3.781 \\
\hline $241 \mathrm{R}-1,16-19$ & 2.865 & 2.45 & & & & & & & & & & \\
\hline $\mathrm{P}$ & & & 5.859 & 6.085 & 6.225 & 6.319 & 6.383 & 6.524 & 6.578 & 6.613 & 6.639 & 6.661 \\
\hline$S$ & & & 3.306 & 3.460 & 3.555 & 3.616 & 3.655 & 3.729 & 3.749 & 3.760 & 3.769 & 3.776 \\
\hline 241R-1, 23-26 & 2.911 & 1.25 & & & & & & & & & & \\
\hline $\mathrm{P}$ & & & 5.821 & 6.167 & 6.353 & 6.461 & 6.527 & 6.663 & 6.724 & 6.766 & 6.800 & 6.827 \\
\hline S & & & 3.276 & 3.416 & 3.506 & 3.569 & 3.613 & 3.714 & 3.751 & 3.774 & 3.791 & 3.805 \\
\hline 241R-1, 101-104 & 2.942 & 0.60 & & & & & & & & & & \\
\hline $\mathrm{P}$ & & & 5.629 & 6.178 & 6.406 & 6.512 & 6.568 & 6.685 & 6.746 & 6.790 & 6.825 & 6.853 \\
\hline$S$ & & & 3.022 & 3.284 & 3.441 & 3.537 & 3.599 & 3.710 & 3.743 & 3.764 & 3.780 & 3.794 \\
\hline $246 \mathrm{R}-1,83-86$ & 2.946 & 0.45 & & & & & & & & & & \\
\hline P & & & 6.076 & 6.395 & 6.539 & 6.614 & 6.659 & 6.766 & 6.825 & 6.867 & 6.900 & 6.927 \\
\hline $\mathrm{S}$ & & & 3.292 & 3.483 & 3.589 & 3.652 & 3.691 & 3.764 & 3.793 & 3.812 & 3.827 & 3.839 \\
\hline $247 \mathrm{R}-1,54-56$ & 2.948 & 0.60 & & & & & & & & & & \\
\hline $\mathrm{P}$ & & & 5.962 & 6.365 & 6.545 & 6.636 & 6.689 & 6.809 & 6.874 & 6.920 & 6.956 & 6.986 \\
\hline$S$ & & & 3.162 & 3.359 & 3.464 & 3.526 & 3.564 & 3.650 & 3.693 & 3.723 & 3.747 & 3.767 \\
\hline $249 \mathrm{R}-1,87-89$ & 2.847 & 3.70 & & & & & & & & & & \\
\hline $\mathrm{P}$ & & & 5.805 & 5.947 & 6.023 & 6.072 & 6.106 & 6.203 & 6.258 & 6.297 & 6.328 & 6.353 \\
\hline $\mathrm{S}$ & & & 3.248 & 3.380 & 3.454 & 3.497 & 3.523 & 3.566 & 3.579 & 3.587 & 3.594 & 3.600 \\
\hline $351 \mathrm{R}-1,18-20$ & 2.879 & 1.56 & & & & & & & & & & \\
\hline $\mathrm{P}$ & & & 5.921 & 6.121 & 6.222 & 6.282 & 6.322 & 6.432 & 6.494 & 6.538 & 6.573 & 6.602 \\
\hline$S$ & & & 3.233 & 3.356 & 3.428 & 3.471 & 3.499 & 3.553 & 3.573 & 3.587 & 3.598 & 3.606 \\
\hline 35 IR-1, 59-62 & 2.940 & 0.51 & & & & & & & & & & \\
\hline $\mathrm{P}$ & & & 5.936 & 6.320 & 6.487 & 6.569 & 6.617 & 6.726 & 6.786 & 6.828 & 6.861 & 6.889 \\
\hline S & & & 3.216 & 3.411 & 3.522 & 3.590 & 3.632 & 3.711 & 3.739 & 3.757 & 3.772 & 3.784 \\
\hline
\end{tabular}

Notes: Density $=\rho\left(\right.$ in $\left.\mathrm{g} / \mathrm{cm}^{3}\right)$, and porosity $=\phi($ in $\%)$. Velocities in $\mathrm{km} / \mathrm{s} . \mathrm{P}=$ compressional-wave velocity $\left(V_{p}\right)$, and $\mathrm{S}=$ shear-wave velocity $\left(V_{s}\right)$. 


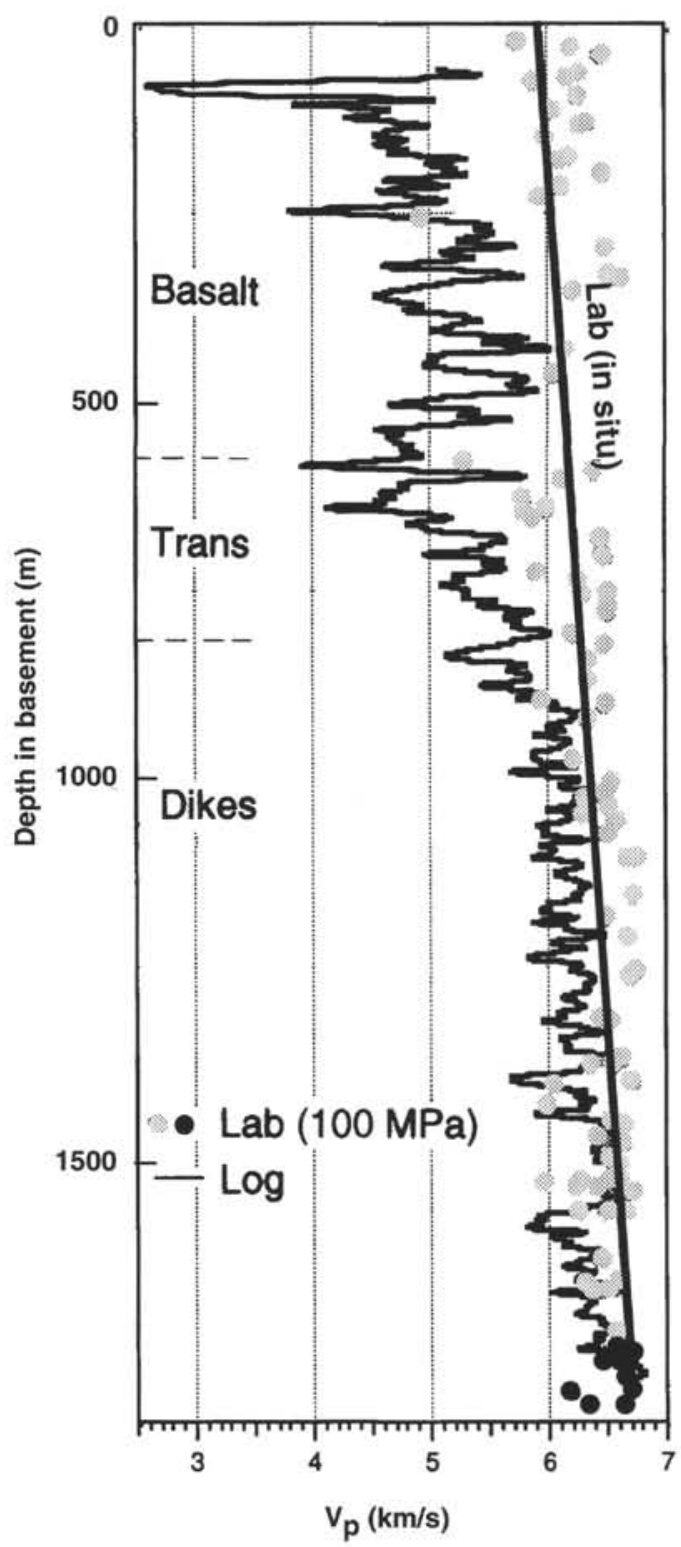

Figure 5. Compressional wave velocity $\left(V_{p}\right)$ vs. depth in Hole 504B determined from logging and laboratory measurements at $100 \mathrm{MPa}$ (solid circles $=$ Leg 148 samples, and shaded circles = previous legs). Solid line shows average laboratory velocity curve after correction for in situ pressures and temperatures. Trans $=$ basalt/dike transition.

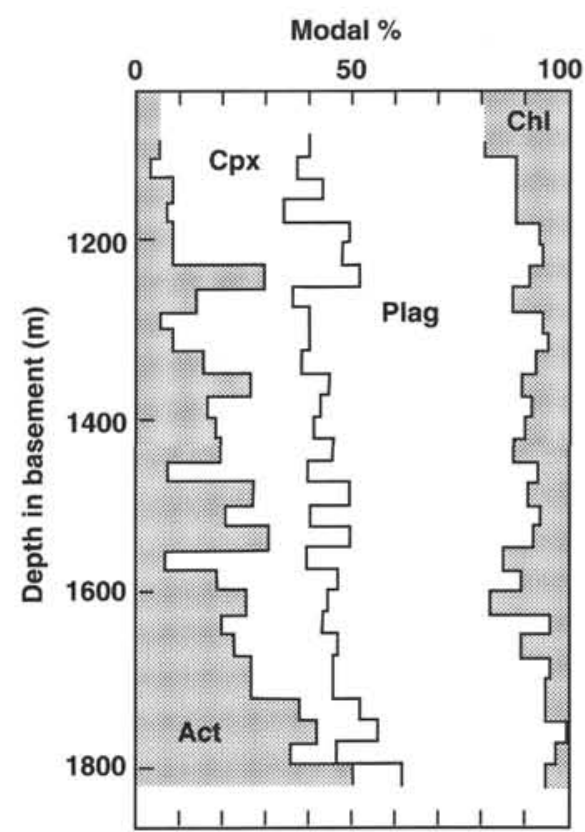

Figure 6. Modal composition vs. depth for the sheeted dikes in Hole 504B determined on the basis of point count averages over $25-\mathrm{m}$ intervals. Act $=$ actinolite, $\mathrm{Cpx}=$ clinopyroxene, $\mathrm{Plag}=$ plagioclase, $\mathrm{Chl}=$ chlorite . 